\title{
JUURNAL_RU
}

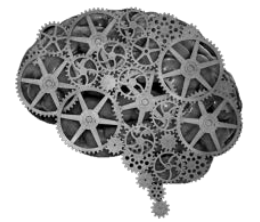

COMPANY GROUP "INTELLEKT"

\author{
Кулинченко А.В. \\ Финансовый университет при Правительстве РФ \\ Москва, Россия
}

doi: 10.18411/lj2016-8-2-07

idsp 000001: lj2016-17-2-07

\section{О взаимосвязи власти и управления общественными делами}

Управление делами общества предполагает наличие организации, которая обеспечивается, прежде всего, деятельной способностью государственных должностных лиц, политических деятелей, политически активных граждан организовать общество, выработать общепринятые правила общежития и механизмы поддержания действующих норм, поставить зримую и понятную цель, объединить усилия для её достижения в интересах общего блага. Такая постановка вопроса актуализирует проблему соотношения управления и властвования в процессе управления обществом, и шире - вопрос о взаимосвязи управления и власти.

Поскольку речь идет об организации, на первый план выходит задача создания урегулированности и порядка на основе формирования и поддержания соответствующих правил, институтов, норм, прежде всего, законов. Но решение этой задачи можно трактовать таким образом, что несомненным приоритетом для властвующего слоя (класса) является именно властвование, а не управление. Последнее представляет собой систему, построенную иерархически; распадается на стратегическое, тактическое, оперативное управление; нисходит до каждого конечного исполнителя, с которым правящей элите вовсе не следует взаимодействовать непосредственно, точнее, руководители нижнего звена не считаются правящей элитой, хотя осуществляют управление на практике. Существуют и противоположные подходы, ставящие во главу угла именно управление, а не властвование. 
В этой связи представляет интерес точка зрения на проблему власти и управления, которую развивают М.В.Рац и С.И.Котельников. Они опираются в своих исследованиях на труды Московского методологического кружка (ММК) под руководством Г.П.Щедровицкого и потому анализируют проблему в более широкой теоретико-методологической перспективе.

Применительно к рассматриваемому в данной статье вопросу обращают на себя внимание следующие идеи и подходы.

Авторы не просто различают властные и управленческие функции государства, но призывают по возможности «минимизировать первые», реализуемые посредством вертикали власти (и связанные с веберовским «легитимным насилием»). Те формы организованности и власти, которые доминируют в общественной жизни, перестают отвечать современным требованиям. Более того, представляют угрозу. Власть как способность заставить людей делать то, что считается нужным, легитимна постольку, поскольку направлена на поддержание существующего и привычного порядка. Напротив, любые нововведения должны согласовываться с теми, чьи интересы они затрагивают: в противном случае нововведения вызывают отторжение и превращаются в насилие. XX век с его тоталитарными режимами и практиками дал немало примеров господства властной мегамашины над жизнью отдельных людей, целых народов и стран. Под мегамашиной авторы понимают социальную пирамиду, выстроенную из индивидов, за каждым из которых закрепляется определённые место и функция, но все они подчинены власти единого центра и лишены возможности целеполагания, $\mathrm{a}$, следовательно, и осуществления осмысленной деятельности. Властное правление, по мнению авторов, лишает исполнителя возможности свободного самоопределения, делает излишним и бесполезным самостоятельный анализ ситуации, исключает свободу его выбора. Власть монологична и ориентирована на воспроизводство существующих отношений и поддержание стабильности, а не нацелена на какие-либо нововведения.

Напротив, в соответствии с подходами ММК, управление (и политика) должны быть ориентированы именно на развитие. В качестве альтернативы властным отношениям авторы рассматривают рефлексивно-диалогические отношения и управленческую деятельность. Управление трактуется как 
деятельность, реализующая представления о будущем управляемой системы. В самом широком понимании управленческая деятельность есть «деятельность над деятельностью». Она предполагает, во-первых, наличие рефлексии и мышления (в особенности, проектного). Во-вторых, основным способом воздействия управляющей системы на управляемую становится коммуникация, их отношения оказываются диалогическими.

Государственная власть, в соответствии с данным подходом, не должна выходить за рамки исполнения правового закона. А управленческие и политические функции могут и должны быть достаточно широкими. Но здесь, по мысли авторов, неприемлемо властное правление, не может быть никакой вертикали, и возможен только диалог с обществом и представителями всех заинтересованных позиций. Подобная организация всего универсума деятельности, основывается на самоопределении каждого из его участников, что, по мнению авторов, должно исключить мегамашинную организацию, обеспечить развитие общества.

Но авторы не только различают (и противопоставляют в определенных отношениях) управление и власть, но видят их единство. Весьма ценной представляется мысль о взаимосвязи управления и власти, (а также политики, нормотворчества, нормоконтроля, руководства и др.) вследствие того, что в их неком идеальном возможном воплощении они соединены пронизывающей эти относительно самостоятельные виды деятельности, так называемой, мыследеятельностью, которая составляет их первооснову. Различными типами мыследеятельности авторы именуют «особые связки мышления и деятельности», сформировавшиеся в ходе исторического процесса разделения труда, обладающие своим местом и функциями в универсуме мышления и деятельности и характеризующиеся специфической - для каждого типа мыследеятельности - системой методов и средств. Общий момент, объединяющий все указанные типы деятельности (мыследеятельности), авторы видят в том, что они не ориентированы непосредственно на производство материальных ценностей. Они призваны делать нечто большее - создавать и поддерживать условия, при которых представители иных родов деятельности могут производить материальные ценности. Следовательно, благодаря им существует общество как таковое. Целенаправленность, осмысленность, 
рефлексия, осознание неудовлетворённости сложившимся положением дел, уникальность выработки личностного отношения субъекта к предмету его мысли и предстоящего действия отличают подлинную природу деятельности людей, присущее ей единство мышления и деятельности (в мыследеятельности).

Многое из вышеизложенного обладает высоким познавательным потенциалом, что-то нуждается в обсуждении и дальнейшей проработке.

В частности, представляется необходимым скорректировать трактовку феномена власти. Ставшее хрестоматийным понимание власти как подчинения воли одних - воле других при помощи разнообразных средств воздействия, как «присвоение чужой воли» - ни в коей мере не ставится под сомнение. Но сами средства воздействия существенно различаются, и принуждение, насилие далеко не самые эффективные методы обеспечения власти. Насилие, «меч», говоря словами И.А.Ильина, не выражает сущность власти, составляет «лишь крайнее и болезненное её средство», её «последнее слово и слабейшую из её опор». Власть есть сила, не только подчиняющая, принуждающая, но и направляющая, объединяющая; организующая не только и не столько посредством насилия, но посредством авторитета, добровольного признания, доверия и сотрудничества. Существует не только насильственная, но и несиловая кооперация в деятельности людей. Поэтому иерархия в обществе - не только выражение отношений господства, торжество механизмов подавления свободного самоопределения людей. Иерархия может быть следствием добровольного и честного принятия людьми превосходства над собой таланта, высоконравственной позиции, плодотворной идеи, проекта преобразований, выдвинутого другими, но отражающего их собственные интересы и цели (субординация на основе добровольного единения воль). Поэтому легитимная власть - это не только согласие со статус-кво, но также и с программой изменений. Властвовать, - писал И.А.Ильин, - значит «налагать свою волю на волю других; однако с тем, чтобы это наложение добровольно принималось теми, кто подчиняется».

Уместно привести точку зрения Н.Лумана, который также полагает, что к насилию прибегают от недостатка власти, имеющей символический характер (символической власти). Саму власть он определяет как «управляемую кодом коммуникацию», «символически генерализированное коммуникативное 
средство». Коммуникативные средства, по Н.Луману, - это некий код генерализированных символов, которые управляют процессом передачи результатов селекции (отбора вариантов). Коммуникативные средства образуются там, где способ отбора, осуществляемого одним из партнеров, одновременно служит для другого мотивационной структурой. Управляемые этими средствами коммуникативные процессы связывают партнеров, каждый из которых реализует свои собственные селективные достижения (свой выбор) и знает, что то же самое делает другой. Данный подход с иных позиций вновь обосновывает знакомый тезис о взаимосвязи власти и управления и важности ненасильственных взаимодействий между людьми.

Если приведенные подходы представляются убедительными, они дают ключ к пониманию вопроса о соотношении и взаимосвязи власти и управления в деятельности правящей элиты.

Однако предварительно уместно сделать некоторые уточнения. Вопервых, непосредственно правящая, политическая элита (или «политический класс») обретает могущество и власть не в глухом одиночестве, а в составе властвующей элиты, включающей также экономическую, военную, культурноинформационную, научную и другие элиты, составляющие опору друг для друга. Это в качестве предварительного условия для властвования и управления выдвигает задачу эффективного взаимодействия элит, их способности под руководством политической элиты обрести политическое единство, пройти путь к выработке таких идей и программ преобразований, которые были бы восприняты обществом.

Во-вторых, сама политическая элита неоднородна, включает приверженцев различных взглядов, идейных течений, партийных пристрастий. Эти различия должны служить развитию многообразия «политических пониманий», способствующего выработке через борьбу мнений единой политической линии при решении актуальных общественных проблем. Неоднородна политическая элита и по составу элитных групп: включает профессиональных политиков и партийных вождей, высших должностных лиц государства, депутатов, губернаторов, высших государственных служащих. Поэтому задачи властвования и управления распределены между ними 
неравномерно, точнее, соотношение власти и управления в деятельности различных групп политической элиты различно.

Государственные служащие в большей мере сосредоточены на поддержании порядка, исполнении закона, регулировании различных сфер общественной жизни на основе норм права. В своей совокупности они составляют важный механизм реализации власти и регулирования общественных процессов как первой, необходимой стадии и функции управления (сохранение и воспроизводство системы как условие её дальнейшего развития).

Политики и государственные деятели не могут ограничиться только этими функциями. Их задача - поиск путей общественного развития на основе широкого общественного диалога. Здесь задачи обретения и реализации власти и управления обществом выступают в теснейшем единстве, идут рука об руку. Политическая власть и управление общественными делами постоянно взаимопревращаются и взаимопереходят друг в друга как различные стадии единого процесса. Ибо обретаемое политическое единство стратегической цели требует, как правило, ее корректировки, вызванной практическими шагами по её достижению в процессе управления, который сам нуждается в политическом согласовании, одобрении, поддержке, общественном согласии, в опоре на власть.

Обеспечение этого политико-управленческого процесса требует от политической элиты способности к выдвижению ярких политических лидеров, которые могли бы объединить общество вокруг своих идей и программ, получить общественную поддержку, повести за собой, мобилизовать все общество для достижения поставленных целей. Политика как деятельность, отправляющаяся от многообразия интересов и целей, через их борьбу - к согласию и солидарности, прорастает здесь в управление развитием общества, достижение программных целей, которое поддерживается и реализуется народным большинством.

Нет необходимости доказывать, что такие лидеры должны обладать выдающимися способностями, высоким профессионализмом, знаниями, опытом, поддержкой и доверием народа. Важным условием народной поддержки является наличие у лидеров высоких моральных качеств. Без этого никакой 
общественный диалог, никакое длительное солидарное движение людей в направлении достижения общих целей и общего блага в процессе поступательного развития общества невозможен. Однако нравственность составляет основу всех социальных взаимодействий, то первое, что лежит вовне и до всяких отношений и коммуникаций между людьми как представителями человеческого рода. Поэтому и лидеры, и элиты должны заботиться о нравственном состоянии народа, способствовать повышению его уровня, чтобы обеспечить возможность солидарной общественной жизни как условия развития общества.

В своей Третьей аксиоме власти И.А.Ильин трактует данный вопрос следующим образом: государственная власть всегда должна осуществляться лучшими людьми, удовлетворяющими этическому и политическому цензу. Народ, принципиально отвергающий правление лучших или не умеющий его организовать и поддерживать является чернью, и демагоги суть его достойные вожди. Демагог обращается к худшему, что есть в человеке, и это худшее полагает в основу политики и власти. Поэтому он есть худший враг народного правосознания и государственности.

К сожалению, в новой России мы видели немало демагогов. Проявились и опасные тенденции деградации, нравственного нисхождения народа и превращения его значительной части в безразличную к судьбе своей Родины чернь. Хочется верить в то, что эти процессы остановлены и обращены вспять. По крайней мере, социологические опросы свидетельствуют в пользу этих надежд. Согласно недавнему опросу «Левада-центра», на первое место в рейтинге качеств депутата наши соотечественники поставили нравственные качества - честность и порядочность (56\%), далее идет профессионализм и образованность (49\%), на третьем месте - близость к народу (37\%). При этом пять лет назад среди качеств депутатов россияне выше всего ценили профессионализм (63\%), активность и энергичность (44\%), близость к народу и открытость (41\%).

Тенденция обозначилась. Будем надеяться, что объединённый патриотической идеей народ сумеет организовать «правление лучших» ответственной и эффективной политической элиты, которая сумеет властвовать 
и управлять развитием общества на основе широкого общественного диалога, в атмосфере согласия и солидарности граждан.

\section{Литература:}

1. Щедровицкий Г.П. Избранные труды. - М.: Шк.Культ.Полит., 1995. - 800 с.

2. Рац М., Котельников С. Власть или управление? Центр гуманитарных технологий. Информационно-аналитический портал. 21.04.2014. [Электронный pecypc] URL: http://gtmarket.ru/laboratory/expertize/6775 (дата обращения: 23.07.2016).

3. Рац М.В. Политика и управление. // Политические исследования. №3 (117). - М.: 2010. С. 132-143.

4. Ильин И.А. О сущности правосознания. Собр. Соч., т. IV. - М.: 1994. С.293300.

5. Луман Никлас. Власть. М.: Праксис, 2001. С. 16-33.

6. Россияне назвали главное качество, которым должен обладать депутат. Москва, 18 июля - РИА Новости. [Электронный ресурс] URL: http://ria.ru/society/20160718/1470079542.html?utm_source=rnews (дата обращения: 23.07.2016). 